\title{
A Political Economy Perspective of the Chinese Government Tactical Behavior *
}

\author{
Gabriele Guggiola ${ }^{\dagger}$
}

\begin{abstract}
In the last decades China has experienced a sustained economic growth that has led to an exceptional increase in its income. Thanks to this performance, China is now one of the main actors on the world economic scene but, in spite of this economic opening, there has been no political opening and not all regions and social groups have equally benefited from the fast growth of the last decades. In the paper I will investigate the tactical behavior kept by the Chinese government in order to pursue economic growth and maintain the power through this development phase. In particular, I will analyze the structural, political and economic determinants of public expenditure and revenue at a local government level in the different Chinese regions between 1995 and 2007. The issue is important in order to the shed some light on the determinants of the government's behavior and to provide some insight on possible future evolutions in Chinese political life.
\end{abstract}

JEL Classification: D72; E62; H72

Keywords: Political Process; Fiscal Policy; Public Expenditure; China

\section{Introduction}

The analysis of governments tactical behavior in democracies is widespread in the literature, and determinants of monetary transfers among different regions ${ }^{1}$ or social groups have been widely studied. In addition to transferring money for redistribution purposes, governments use monetary transfers for electoral

*This paper has been realized within "Vittorio Alfieri 06/07 Project: The two emerging economies of Asia (China and India)". Financial support from Fondazione CRT is gratefully acknowledged. I thank the participants involved in the project for the useful discussions about the issues analyzed in the paper. A special thanks goes to Mario Deaglio, Anna Marenzi, Cristina Mitaritonna, Lino Sau, Raffaello Seri and Vittorio Valli for their useful suggestions.

${ }^{\dagger}$ Department of Economics, University of Insubria, via Monte Generoso 71, 21100 Varese, Italy and Centro di Ricerca e Documentazione "Luigi Einaudi", via Ponza 4, 10121 Torino, Italy; e_mail: gabriele.guggiola@uninsubria.it.

${ }^{1}$ Following the terminology used in the Chinese Statistical Yearbook I will define as regions the 22 provinces (Taiwan has been excluded for the non availability of comparable data), the 5 autonomous regions and the 3 municipalities (Chongqinq will not be included because data are available only from 1998, when it acquired the status of municipality). 
purposes and candidates, or parties, in an electoral race are used to promising different transfer schedules to maximize the expected share of votes (or the expected probability of being elected). This is not surprising: in a democratic context candidates should win an election before gaining the right to govern.

In non democracies the dictator, or the ruling party, is expected to keep the power constraining political freedom, limiting the activities of adverse parties and free press with violence and torture. Nevertheless, also in autocracies there should be some role for popular consensus. Dictatorships can have troubled lives if wide interest groups and social classes strongly oppose them, and the force could be insufficient to avoid the threat of a revolution. As pointed out in Alesina and Rodrik (1994), "even a dictator cannot completely ignore social demands, for fear of being overthrown". There is anyway little contribution in the literature analyzing whether evidence of tactical can be found in a non democratic institutional environment.

In the paper I will therefore analyze the behavior of a non democratic government, to find possible evidence of tactical transfers aiming at maintaining the consensus among different social classes or among citizens living in different regions. In particular, I'll study the transfers operated among different regions and social groups by the Chinese government in the years between 1995 and 2007.

There are several reasons that makes China an attractive case study.

In the last decades China has experienced a sustained economic growth that has lead to an exceptional increase in its income and, thanks to this performance, it has become one of the major players in the world economic scene. Chinese economic growth has been exceptional not only for its intensity but, also, for the political conditions in which it has taken place. Despite being drawn by the introduction of free market mechanisms and by an increasing integration with international markets, the opening process has been regulated and controlled by the Chinese government, that has dictated its timing and its conditions. Moreover, no political opening has taken place side by side to economic opening. No democratic reform has been undertaken and the political scenario does not suggest that any significant change is behind the corner. How has the Chinese government managed to reach high growth rates, to increase average education of Chinese citizens and to open its economy to foreign firms and capitals without leaving room for any kind of democratization process? How has the government been able to pursue this aim in a country of more than a billion of inhabitants, composed by highly differentiated regions from an economic, geographical and social point of view?

Second, not all Chinese regions were equally involved in the development process. Special purpose areas were the first to be allowed to trade more freely with foreign countries and to be provided with business friendly laws, infrastructures and institutions suitable for economic development and foreign capitals attraction. As a result, these regions, mainly located on the East Coast, rapidly developed and are now among the world economically most dynamic areas. Other regions were left completely out of the development process and are still characterized by extreme poorness: agriculture is still the main activity 
and a great part of the labour force try, within the limits imposed by Hukou ${ }^{2}$, to migrate towards the coast. Income inequality among regions (Chang, 2002; Fan et al., 2002; Lee, 2000) and among social classes (Lu, 2002; Xu and Zou, 2000) has raised and not diminished during the last decades. Is the government trying to contrast this trend, or the strategy of developing first some selected areas prevails also in the public expenditure allocation mechanism? In addition, if there is some redistribution via monetary transfers, to what extent this is ascribable to equity purposes and to what extent this redistribution is tactical, aiming at reducing dissatisfaction in poorer regions and to limit the threat of social unrest?

Third, China is an attractive case study because of its social and geographical fragmentation. China is a wide country, made up of geographically remote regions, inhabited by different ethnic groups. Some regions are poorer than others, characterized by a net prevalence of agricultural sector and the differences between rural and urban zones are wide; moreover people do not easily change their location, due to the strict limits imposed by the Hukou. The Chinese government could, if willing to do so, select with an high degree of precision which kind of socioeconomic group to favor in transferring resources. It's therefore possible to observe which social groups or geographical regions are preferred recipients of monetary transfers.

I will analyze the structural, political and economic determinants of public expenditure and revenue at a local government level in the different Chinese regions. The analysis adds on the literature in two ways. First, it offers an additional, and innovative, interpretation of the Chinese government behavior and of the growing disparities observed within and among different Chinese regions. Furthermore, it offers some insights on possible future evolutions of Chinese political scene that, up to now, have shown a very low degree of political reforms.

The paper proceeds as follows. Section 2 surveys the related literature and section 3 describes some peculiarities of the Chinese economic opening process. The econometric model and the results concerning total revenues and expenditure will be analyzed in section 4 while section 5 deals with the determinants of social and structural expenditure. Section 6 concludes.

\section{Related literature}

In a democratic context, candidates propose transfer schedules (or "pork barrel" projects) in order to maximize the expected share of votes or the probability of winning the election. Literature on optimal transfer schedules is wide but one of the main conclusions that has emerged is that candidates either favor their supporters or swing voters. Dixit and Londregan (1996) strongly support the thesis that swing voters, more sensitive to monetary promises than to ideological issues, are favored in the redistribution game; Cox and McCubbins (1986), on

\footnotetext{
${ }^{2}$ Chinese household registration system.
} 
the contrary, advance a risk premium argument sustaining that supporters are favored in the redistribution game.

Do the rationales behind these conclusions hold also in a non democratic environment? According to my point of view, they partially do. Autocratic governments do not need to gain day by day support, neither do they face electoral races, but they still need to rely on a basis of consensus to maintain the power and not to incur in serious revolutionary threats. As Wintrobe (1990) noticed, "a dictator provides individuals or interest groups with public services or patronage in exchange for support". The mechanisms to gain this support may well be similar, or at least comparable, to those known in modern democracies. It's realistic to suppose that autocracies will not favor opposition groups, which may continue to represent a threat whatever the autocrat behavior is towards them. However, if we compare the performances of "swing citizens" (indifferent towards the regime) with the one of regime supporters, it's not clear, a priori, whether the first or the latter should obtain a more favorable treatment in a dictatorship. From an anecdotal point of view, it seems that regime supporters generally receive a good treatment (for an empirical analysis of Chinese case see Dickson and Rost Rublee, 2000, and Li et al., 2007), but it's not clear how to measure possible advantages of swing groups, and the existent literature does not help much to clarify the issue.

According both to Cox and McCubbins (1986) and to Dixit and Londregan (1996) poor social classes are more pliable to monetary promises. That is obvious in a democratic contest, because poor will be more attracted by the promise of monetary transfers than by ideological issues. In a non democratic framework, this reasoning still holds, at least partially. Very poor people may acknowledge more than others monetary transfers and the autocrat, therefore, might be temped to gain their consensus by transferring resources towards them.

Acemoglu and Robinson (2000, 2001 and 2006), Lizzeri and Persico (2004) and Conley and Temimi (2001) analyze the issue of democratization from an historical perspective. According to Acemoglu and Robinson (2000, 2001 and 2006) significant threats of revolution can contribute to political reforms inducing the elite in power to increase redistribution or, in extreme cases, to opt for democratization. If income inequality is too high, redistribution may not be sufficient, since the elite lacks of commitment technology for future periods and the disenfranchised may prefer a revolution to a "one shot redistribution". According to their model, income inequality usually reaches its top in the years before the start of a democratization process. Is this the case of China? Income inequality has risen in the last decade, instead of decreasing along with economic growth, and a certain degree of redistribution might be necessary in order to avoid dissatisfaction among poor citizens. Lizzeri and Persico (2004) sustain that the progressive suffrage extension that has transformed Britain in one of the most important world democracies had been due to the incapability of the previous institutional setting (based on an highly restricted and census based suffrage) to provide basic public goods (sanitation, public health, education), whose demand was increasing during the urbanization decades. The provision of public service in large urban conglomeration has been, and will be, an issue of 
primary importance in the Chinese development process. According to Conley and Temimi (2001), a democratization process is more likely to happen when group preferences are more opposed, and China offers an example of coexistence of very different ethnics and social groups.

Giavazzi and Tabellini (2005) compare two possible paths of reforms. Some countries open their economies and then proceed with political reforms, others do the opposite. It appears that countries that follow the first path perform better and that would partially explain Chinese economic performance. The issue is whether political reforms will follow to economic opening: if that will be the case, China is following an efficient "reform path". Notice how, analyzing the transition towards democracy in former socialist countries, also Krussel and Rios-Rull (2002) give credit to the idea that temporarily restricting voting rights at the beginning of the transition process might enhance economic performance.

The issue of rising income inequality in China is discussed in Chang (2002), Fan et al. (2002), Lee (2000), Lu (2002), Yang (1999) and Yang and Zhou (1999). According to Chang (2002) rural-urban income gap is the main source of the high Chinese disparities. The causes may be traced back to differences in marginal productivity, to restrictions to inter regional mobility (Yang and Zhou, 1999) or to increased urban subsidies (Yang, 1999). I will come back on this issue in the following sections.

Dickson and Rost Rublee (2000) and Li et al. (2007) analyze the advantages of being member of the Chinese Communist Party while Kenny and Winer (2006) and Mulligan et al. (2004), from a general perspective, discuss the effects of institutions on tax structure and public policies.

Finally, repression is the usual mean, perhaps the main, that dictatorships use to maintain the power (see, among others, Wintrobe, 1990) but I will not examine this point. This is surely relevant in the Chinese case, but I want to see whether, aside repression, the Chinese government is also relying on some kind of incentive mechanism in order to remain on power.

\section{Peculiarities of Chinese economic opening pro- cess}

China has undergone a rapid and wide process of economic opening. In 1980, exports of goods and services represented just $10 \%$ of the GDP, but reached values around $30 \%$ of the GDP in the first years of the new millennium. Similar data can be observed with reference to imports. Foreign direct investments, which were almost inexistent in 1980, represented a 2,84\% of the GDP in 2004; in the same year one fifth of Chinese industries were financed from abroad. Reforms have been undertaken in the financial sector, though much should still be done (Allen et al., 2005), and the direct intervention of the government in the national economy has decreased, with a reduction of the role played by state owned enterprises (SOE). As a result of this opening process, Chinese income per capita has increased dramatically in the last decades and China has passed 
through a phase of strong economic growth, even if no relevant changes have happened on the political scene. According to Wintrobe (1990) a similar path is rational for a totalitarian regime, that should find optimal, in order to maintain the power, to (partially) relax repression and then implement economic reforms in order to increase the loyalty of the citizens.

China has never begun a democratization process and political and civil rights are, still, heavily limited by the government. The "polity" indicator of Polity Dataset ranges from a value of "-10", assigned to autocratic political systems, to a value of " +10 ", assigned to full democracies. Since 1976 China has been assigned a score of -7 (autocracy) and no improvement has occurred, not even for limited periods. In spite of this absence of reforms, political stability has never seriously been threatened in the last decades.

This historical pattern is somehow rare. Transition towards market economy and democracy in former communist countries of Eastern Europe has been caused by a traumatic break, with revolutions occurring and with a rapid switch of political regime. Observing the history of Chinese "neighbors", we encounter a wide range of political regimes. India, which is similar to China as dimensions, is a democracy and its institutions have roots originating in the Commonwealth age. South Korea (the wealthiest country in the area, together with Japan) is today a modern democracy while Indonesia, the other relevant country in the area, is still at an early stage of democracy and has often been affected by political disorders and social unrest. In China no serious threat of revolution has become, up to now, concrete, neither in the regions that have benefited more from economic growth, nor in the regions that have been largely excluded from this process. How has the Chinese government managed to maintain a strict control over a country which is so geographically wide and so socially differentiated?

Surely, the control over the political activities has been strict and the political freedom has been heavily limited by the Chinese government. China, since 1978, has constantly scored 4 in PARREG ${ }^{3}$ indicator of Polity Dataset, denoting a restricted ${ }^{4}$ regulation of participation. In the PARCOMP ${ }^{5}$ indicator the score, in the same period, has been constantly $1^{6}$, indicating that "no significant oppositional activity is permitted outside the ranks of the regime and ruling party." But this can be only an aspect of the whole story. USSR, Bulgaria, Czechoslovakia, Romania, just to mention some of the eastern European transitioning countries, have scored, during the communist era, the same as China in the two indicators analyzed but, nevertheless, their autocratic governments were not able to maintain the power.

There are at least two relevant issues that might explain the differences between the Chinese case and former communist transition economies. First,

\footnotetext{
${ }^{3}$ Regulation of participation.

4"Some organized political participation is permitted without intense factionalism but significant groups, issues, and/or types of conventional participation are regularly excluded from the political process."

${ }^{5}$ Competitiveness of participation.

${ }^{6}$ Repressed.
} 
the Chinese government has pursued a more farseeing approach to economic matters, aware that growth is necessary in order to reduce the pressure towards a regime change and realizing that a certain degree of economic liberalization is necessary for growth. Second, the Chinese government has apparently chosen different development and political strategies for the different regions of its wide territories.

In the following part of the paper I will try to explore to what extent this behavior can be led back to a precise strategy on behalf of the Chinese government, which have been the drivers of this strategy and which can be the possible future evolutions. I want to test whether the above described political economy incentives could have had some effects in shaping government decisions. Moreover, I want to find out whether the Chinese government is financing in a proportionally higher degree the poorer regions, so to avoid potential threats of revolutions or disorders, or it is betting on coastal and more economically dynamic zones, in order to favor a fast growth in those regions where potential demand for democracy is higher.

\section{The econometric analysis}

In this section we will illustrate and discuss the results of the econometric analysis performed in order to explain the main determinants of public expenditure and revenue at a regional level. Section 5 will be dedicated to the analysis of particular types of public expenditure: social and structural expenditure.

\subsection{Structural, political and socioeconomic determinants of public expenditure and revenues}

I will consider a set of structural, political and socioeconomic variables in order to analyze the determinants of local governments expenditure and revenue in thirty Chinese regions over the period 1995-2007. The aim of the econometric model is to analyze the allocation of public funds across the different regions so to find out whether there have been tactical behaviors on behalf of the Chinese government.

The dependent variables considered will be (log) per capita $\mathrm{GRP}^{7}$, (log) regional population, share of import and export over GRP, value of imports and exports of foreign-funded enterprises over GRP, urban-rural consumption ratio, share of primary industry over GRP, dependency ratio, illiteracy rate and a set of dummy variables accounting for congress cycles and the Asian crisis of 1997.

GRP per capita entails both a structural and a political component. According to political economy literature (Dixit and Londregan, 1996; Cox and McCubbins, 1986), lower income citizens are more responsive to monetary promises and transfers. Hence, public expenditure should be higher (and revenues lower)

\footnotetext{
${ }^{7}$ Gross regional product.
} 
in poorer regions, considering that marginal transfers should have a greater marginal impact in maintaining political loyalty to the regime and assuring stability. On the other side demand for public services, and especially for health service provision, is structurally higher in high income regions than in low income ones.

Regions with a greater dependency ratio should be a favored recipient of public expenditure, given that expenditure on health service provision is higher for the younger and the elder and expenditure on schooling is consistently determined by the ratio of young people with respect to the total population. In any event, also in this case, political issues might arise. Demand for democracy and for political reforms should be higher in the more educated part of the population and the government might deliberately decide to increase transfers of resources towards regions where average education level is higher and dependency ratio lower ${ }^{8}$, in order to increase political loyalty among more demanding citizens and to prevent social unrest. Following a similar reasoning, if the government is pursuing equity goals public expenditure (specially on schooling) should be higher in regions with an high illiteracy rate (ie.: in interior regions and in the countryside). If, vice versa, the ultimate goal of the government is to increase loyalty of high demanding rising middle class, resources will be concentrated in urban conglomeration where illiteracy rate is reasonably lower.

The total value of import-exports by location of importers/exporters over GRP will be considered in order to test whether Chinese government is favoring, in the redistribution game, more open and developed regions with the aim of pushing the growth rates in some clearly identified areas (the special economic zones), leaving for the future the task of promoting nationwide growth. We also want to check for possible second order effects due to the relevance of foreignfunded enterprises regarding total trade, by allowing for an interaction term between imports and exports of foreign-funded enterprises and overall imports and exports.

Urban-rural dichotomy should be used to test whether the government is building a more developed welfare system in the urban agglomerate than in the rural areas ${ }^{9}$. We opted for urban-rural consumption ratio to account for the increasing inequalities among rural and urban citizens and for the increasing disparities within regions.

Following Mulligan et al. (2004), we allow for possible pool effects in public policies ${ }^{10}$ by considering total population within the set of independent variables. We also consider the total share of primary industry ${ }^{11}$ over GRP as a proxy for the level of development and as a sign of the fraction of population

\footnotetext{
${ }^{8}$ Middle-aged citizens are, potentially, the most harmful to the regime: elderly might be politically "captured" by the regime ideology and have less to gain from a status quo reversal; very young people (under 14) do not take an active political role.

${ }^{9}$ Notice that, as pointed out in Lizzeri and Persico (2004), in Great Britain the urbanization process led to a substantive suffrage extension, in order to satisfy the growing needs for public services (sanitation at first) in big cities. For the Chinese government the satisfaction of this demand could be a critical point in order to avoid future political instability.

${ }^{10}$ Public sector may exhibit economies of scale.

${ }^{11}$ Agriculture, forestry, animal husbandry, fishery and services in support of these industries.
} 
that has less easy access to different public programs.

A set of dummy variables will then be considered to account for congressional cycles and Asian crisis of 1997. Concerning the latter, we set up a dummy equal to one for years 1997, the year in which the crisis in far-east Asian countries exploded, and for 1998-1999, the only two years over the whole considered period in which Chines GDP grew at a rate lower than $8 \%$. The dummy aims at intercepting possible consequences of the crisis on Chinese government budget policies.

Finally, China is not a democracy and so there is no place for classical electoral cycles (with governments usually spending more in correspondence of an electoral race). In any case, Chinese political and economic life is organized in five year plans, approved during the periodical congresses of the Chinese Communist Party. Is there any link between the timing of the plans and the expenditure when congress is forthcoming? Could it be the case that expenditure increases shortly before each congress, when is necessary to reach the planned results and to gain political visibility in view of the imminent political meeting? A specific dummy identifying the year preceding each congress and congress year and a second dummy for the year immediately following each congress are inserted to allow intercepting these possible effects.

\subsection{Explaining the expenditure function}

In Table 1 the results of the regression of regional government expenditure on the identified independent variables are displayed. A pooled least square technique with fixed effects (accounting for regional unobserved variables) is used in the regression and the results are shown in the first two columns. Both a model with contemporaneous effects (column 1) and a model with lagged independent variables $^{12}$ (column 2) are considered. A time trend is always accounted for. In order to test for the robustness of the estimates feasible GLS assuming crosssection heteroskedasticity are also determined (column 3 and 4). Data is mainly from China Statistical Yearbook (various issues) ${ }^{13}$, provided by the National Bureau of Statistics of China.

The estimated model is therefore:

$y_{i t}=\beta_{0}+\beta_{1} \log \left(\right.$ GRP per capita $\left.{ }_{i t}\right)+\beta_{2} \log \left(P O P_{i t}\right)+\beta_{3} I M P E X P_{i t}+$ $\beta_{4} I M P E X P_{i t} \times F F E_{i t}+\beta_{5} U R C O N S_{i t}+\beta_{6} I S E C T_{i t}+\beta_{7} P R E C O N G_{t}+$ $\beta_{8}$ POSTCONG $_{t}+\beta_{9} I L L_{i t}+\beta_{10} D E P_{i t}+\beta_{11} A S C R I S_{t}+\phi_{i}+\epsilon_{i t}$

where $y_{i t}$ represents (log) local per capita public expenditure in region $i$ at time $t$ while $\phi_{i}$ represent region $i$ specific fixed effects ${ }^{14}$.

Local government expenditure is positively correlated with GRP per capita, import and export share over GRP and urban-rural consumption ratio. The coefficients are significant over almost all the econometric specifications, denoting the robustness of the estimate. GRP per capita positively influences public expenditure, showing how the demand effect (higher income citizens demand

\footnotetext{
${ }^{12}$ With exclusion of year specific dummies.

${ }^{13} \mathrm{~A}$ detailed description of the data used in the regression is provided in Appendix I.

${ }^{14}$ All monetary values used are in 2000 constant values.
} 
Table 1: Government expenditure by region (per capita)

\begin{tabular}{|c|c|c|c|c|}
\hline \multirow{2}{*}{$\begin{array}{l}\text { Variables } \\
\text { GRP per capita } \\
\text { (log) }\end{array}$} & \multicolumn{2}{|c|}{ Pooled LS (1) } & \multicolumn{2}{|c|}{ Pooled EGLS (1) (2) } \\
\hline & $\begin{array}{c}0,519^{\star \star \star} \\
(0,101)\end{array}$ & $\begin{array}{c}0,474^{\star \star \star} \\
(0,132)\end{array}$ & $\begin{array}{c}0,384^{\star \star \star} \\
(0,063)\end{array}$ & $\begin{array}{c}0,289^{\star \star \star} \\
(0,061)\end{array}$ \\
\hline $\begin{array}{l}\text { Population } \\
\text { (log) }\end{array}$ & $\begin{array}{c}-0,509^{\star \star \star} \\
(0,192)\end{array}$ & $\begin{array}{l}-0,349^{*} \\
(0,206)\end{array}$ & $\begin{array}{c}-0,585^{\star \star \star} \\
(0,199)\end{array}$ & $\begin{array}{l}-0,305^{\star *} \\
(0,155)\end{array}$ \\
\hline $\begin{array}{l}\text { Imp+Exp } \\
\text { (over GRP) }\end{array}$ & $\begin{array}{c}0,380^{\star * \star} \\
(0,064)\end{array}$ & $\begin{array}{c}0,467^{\star * *} \\
(0,069)\end{array}$ & $\begin{array}{c}0,434^{\star * *} \\
(0,062)\end{array}$ & $\begin{array}{r}0,476^{* * *} \\
(0,044)\end{array}$ \\
\hline $\begin{array}{l}\mathrm{FFE}^{\star}(\operatorname{Imp}+\operatorname{Exp}) \\
\text { (over GRP) }\end{array}$ & $\begin{array}{c}-0,202^{\star \star \star} \\
(0,051)\end{array}$ & $\begin{array}{c}-0,289^{\star \star \star} \\
(0,048)\end{array}$ & $\begin{array}{c}-0,207^{\star \star \star} \\
(0,043)\end{array}$ & $\begin{array}{c}-0,280^{\star \star \star} \\
(0,023)\end{array}$ \\
\hline $\begin{array}{l}\text { Urban-rural } \\
\text { consumption ratio }\end{array}$ & $\begin{array}{c}0,044^{\star \star *} \\
(0,016)\end{array}$ & $\begin{array}{c}0,025 \\
(0,015)\end{array}$ & $\begin{array}{c}0,043^{\star * \star} \\
(0,012)\end{array}$ & $\begin{array}{c}0,031^{\text {*** }} \\
(0,008)\end{array}$ \\
\hline $\begin{array}{l}\text { Primary industry } \\
\text { (share of GRP) }\end{array}$ & $\begin{array}{c}-0,976^{\star \star \star} \\
(0,234)\end{array}$ & $\begin{array}{c}-0,965^{\star \star} \\
(0,373)\end{array}$ & $\begin{array}{c}-1,298^{\star \star \star} \\
(0,165)\end{array}$ & $\begin{array}{c}-1,204^{\star \star \star} \\
(0,192)\end{array}$ \\
\hline Pre-congress & $\begin{array}{c}0,034 \\
(0,022)\end{array}$ & $\begin{array}{c}0,015 \\
(0,017)\end{array}$ & $\begin{array}{c}0,021 \\
(0,015)\end{array}$ & $\begin{array}{l}0,021^{\star *} \\
(0,010)\end{array}$ \\
\hline Post-congress & $\begin{array}{c}0,018 \\
(0,022)\end{array}$ & $\begin{array}{l}-0,005 \\
(0,017)\end{array}$ & $\begin{array}{l}3,37 \mathrm{E}-05 \\
(0,015)\end{array}$ & $\begin{array}{l}-0,014 \\
(0,010)\end{array}$ \\
\hline Illiteracy rate & $\begin{array}{l}-0,236 \\
(0,257)\end{array}$ & $\begin{array}{c}-1,011^{\star \star \star} \\
(0,181)\end{array}$ & $\begin{array}{l}-0,073 \\
(0,210)\end{array}$ & $\begin{array}{c}-0,765^{\star \star \star} \\
(0,100)\end{array}$ \\
\hline Dependency ratio & $\begin{array}{c}0,142 \\
(0,209)\end{array}$ & $\begin{array}{l}0,459^{* *} \\
(0,207)\end{array}$ & $\begin{array}{c}0,210 \\
(0,182)\end{array}$ & $\begin{array}{c}0,399 \\
(0,071)\end{array}$ \\
\hline $\begin{array}{l}\text { Dummy Asian } \\
\text { crisis }\end{array}$ & $\begin{array}{l}-0,056 \\
(0,035)\end{array}$ & $\begin{array}{l}-0,033^{*} \\
(0,019)\end{array}$ & $\begin{array}{l}-0,037 \\
(0,022)\end{array}$ & $\begin{array}{l}-0,003 \\
(0,009)\end{array}$ \\
\hline Time trend & Yes & Yes & Yes & Yes \\
\hline Lagged indep. var. & No & Yes & No & Yes \\
\hline $\mathrm{N}^{\circ}$ observations & 390 & 360 & 390 & 360 \\
\hline Adj. R sq. & 0,982 & 0,981 & --- & --- \\
\hline Log likelihood & 353,994 & 330,921 & --- & --- \\
\hline F-Statistic & $525,85^{\star \star *}$ & $462,00^{\star \star \star}$ & --- & --- \\
\hline
\end{tabular}

(1) White cross-section standard errors (d.f. corrected)

(2) Cross-section weights

Regional fixed effects always included in the estimations. 
more public services) prevails over the redistribution purposes. Regions that are more open to foreign trade are better recipients of public resources, revealing a special "care" on behalf of the government towards these high growth rate regions. Positive coefficients on urban-rural consumption ratio reveals, on the other side, some kind of redistribution purpose aiming at solving the disparity that, according to Chang (2002), is becoming the most relevant in determining inequality rise in China and risks to threaten political stability.

Spending, vice versa, is negatively related to the share of primary industry and illiteracy rate, denoting a low interest towards less developed and rural regions. Specially the former relation is very strong: rural zones receive inadequate public services and peasants, as observed in various literature contributions, are excluded from most of the transfers schemes.

Spending, as noticed, is higher in internationally more open regions (positive coefficient on total trade over GRP variable). There is, anyway, a non linear relation: government "invest" more political resources on more economically open regions but then, holding this variable fixed, more resources are allocated where domestic (perhaps state owned) firms are leading. Spending is, in fact, negatively correlated with the share of import and exports of foreign-funded enterprises over GRP.

Total population has a negative impact on per capita public expenditure, denoting a pool and a scale effect in the management of public services. Negative, but generally not significant, is also the effect related to Asian crisis dummy. Though a priori we expected a negative sign, Chinese public debt, foreign liabilities and debt ratio were always under control and the economic downturn in the area did not cause major public policy changes.

The increase in public expenditure before a congress is positive (but not significant) while the effect of post congress dummy is ambiguous and not significant.

The absence of a significant effect of dependency ratio on public expenditure seems counter intuitive, at least if interpreted according to western countries parameters. In fact, an higher dependency ratio means an higher proportion of very young and very old people, which are usually better recipients of public expenditure, by way of the schooling, health and pension systems. Nevertheless this result is less counter intuitive if we consider some features of Chinese society. First, we must take into consideration that an advanced pension system ${ }^{15}$ does not exist in China, so that an increase in the proportion of old people does not always determine a direct and relevant increase in public expenditure. Moreover, considering the traditional structure of Chinese family (three overlapping generations often belonging to a same family nucleus and insuring reciprocal welfare and subsistence), the burden of an higher dependency rate might fall mainly on the family itself and not on the public balance.

\footnotetext{
${ }^{15}$ Public pension system is clearly underdeveloped in China and it's becoming a main issue of the policy debate.
} 
Table 2: Government revenue by region (per capita)

\begin{tabular}{|c|c|c|c|c|}
\hline \multirow{2}{*}{$\begin{array}{l}\text { Variables } \\
\text { GRP per capita } \\
\text { (log) }\end{array}$} & \multicolumn{2}{|c|}{ Pooled LS (1) } & \multicolumn{2}{|c|}{ Pooled EGLS (1) (2) } \\
\hline & $\begin{array}{l}0,920 * * * \\
(0,080)\end{array}$ & $\begin{array}{l}0,859^{* * *} \\
(0,075)\end{array}$ & $\begin{array}{l}0,900 \cdots * \cdots \\
(0,070)\end{array}$ & $\begin{array}{l}0,827 \cdots * \\
(0,051)\end{array}$ \\
\hline $\begin{array}{l}\text { Population } \\
\text { (log) }\end{array}$ & $\begin{array}{l}0,244 \\
(0,165)\end{array}$ & $\begin{array}{c}0,293 \\
(0,194)\end{array}$ & $\begin{array}{l}0,067 \\
(0,163)\end{array}$ & $\begin{array}{l}0,174 \\
(0,173)\end{array}$ \\
\hline $\begin{array}{l}\text { Imp+Exp } \\
\text { (over GRP) }\end{array}$ & $\begin{array}{c}0,717^{* * *} \\
(0,091)\end{array}$ & $\begin{array}{l}0,754^{* * *} \\
(0,132)\end{array}$ & $\begin{array}{l}0,519 * \cdots \\
(0,066)\end{array}$ & $\begin{array}{l}0,598^{* * *} \\
(0,066)\end{array}$ \\
\hline $\begin{array}{l}\text { FFE*(Imp+Exp) } \\
\text { (over GRP) }\end{array}$ & $\begin{array}{c}-0,273^{* * *} \\
(0,066)\end{array}$ & $\begin{array}{c}-0,329 * * * \\
(0,092)\end{array}$ & $\begin{array}{c}-0,129 * * * \\
(0,030)\end{array}$ & $\begin{array}{c}-0,198^{* * *} \\
(0,049)\end{array}$ \\
\hline $\begin{array}{l}\text { Urban-rural } \\
\text { consumption ratio }\end{array}$ & $\begin{array}{c}3,97 \mathrm{E}-05 \\
(0,008)\end{array}$ & $\begin{array}{l}-0,016^{*} \\
(0,009)\end{array}$ & $\begin{array}{l}0,007 \\
(0,007)\end{array}$ & $\begin{array}{l}-0,012^{*} \\
(0,006)\end{array}$ \\
\hline $\begin{array}{l}\text { Primary industry } \\
\text { (share of GRP) }\end{array}$ & $\begin{array}{l}-0,057 \\
(0,152)\end{array}$ & $\begin{array}{l}-0,457^{* * *} \\
(0,166)\end{array}$ & $\begin{array}{l}-0,212 \\
(0,180)\end{array}$ & $\begin{array}{l}-0,699^{\text {t****}}(0,167) \\
(0,0)\end{array}$ \\
\hline Pre-congress & $\begin{array}{l}0,040 \\
(0,025)\end{array}$ & $\begin{array}{l}0,011 \\
(0,022)\end{array}$ & $\begin{array}{l}0,037^{*} \\
(0,019)\end{array}$ & $\begin{array}{r}0,015 \\
(0,014)\end{array}$ \\
\hline Post-congress & $\begin{array}{l}0,018 \\
(0,028)\end{array}$ & $\begin{array}{l}-3,81 \mathrm{E}-05 \\
(0,019)\end{array}$ & $\begin{array}{l}0,013 \\
(0,024)\end{array}$ & $\begin{array}{l}-0,000 \\
(0,013)\end{array}$ \\
\hline Illiteracy rate & $\begin{array}{l}-0,569 * * \\
(0,220)\end{array}$ & $\begin{array}{l}-0,147 \\
(0,173)\end{array}$ & $\begin{array}{c}-0,490^{* * * *} \\
(0,174)\end{array}$ & $\begin{array}{l}-0,036 \\
0,129)\end{array}$ \\
\hline Dependency ratio & $\begin{array}{l}0,224^{* * *} \\
(0,074)\end{array}$ & $\begin{array}{l}0,167^{*} \\
(0,100)\end{array}$ & $\begin{array}{c}0,288^{* * * *} \\
0,084)\end{array}$ & $\begin{array}{c}0,232^{2 * * *} \\
(0,075)\end{array}$ \\
\hline $\begin{array}{l}\text { Dummy Asian } \\
\text { crisis }\end{array}$ & $\begin{array}{l}0,056 \\
(0,036)\end{array}$ & $\begin{array}{l}0,032 \\
(0,025)\end{array}$ & $\begin{array}{l}0,051^{*} \\
(0,031)\end{array}$ & $\begin{array}{l}0,033 \\
(0,014)\end{array}$ \\
\hline Time trend & Yes & Yes & Yes & Yes \\
\hline Lagged indep. var. & No & Yes & No & Yes \\
\hline$N^{\circ}$ observations & 390 & 360 & 390 & 360 \\
\hline Adj. R sq. & 0,988 & 0,988 & -- & -- \\
\hline Log likelihood & 401,528 & 381,798 & --- & --- \\
\hline F-Statistic & $782,31^{* * * *}$ & $733,98^{* * *}$ & --- & --- \\
\hline
\end{tabular}

(1) White cross-section standard errors (d.f. corrected)

(2) Cross-section weights

Lev. Of sign.: $\left(^{* * *}\right)=1 \%,\left(^{* *}\right)=5 \%,\left(^{*}\right)=1 \%$

Regional fixed effects always included in the estimations.

\subsection{Explaining the revenue function}

Analysis of the revenue function is interesting in order to understand if the global amount of resources collected from different regions depends on the political and economic variables already considered in the analysis of the expenditure function.

Richer regions contribute more, in per capita terms, to government revenues, which is sensible and consistent with the "ability to pay" principle of public economics. Internationally open regions contribute more than closed regions, and also this fact is sensible, for two reasons. First, because more internationally open regions also exhibit better economic performances. Second, internationally open regions are more densely populated of enterprises and dictatorships rely much more on corporate taxation and on taxes on trade than on personal income taxes (Kenny and Winer, 2006). Notice that, however, once trade variable is 
accounted for, regions with an higher share of foreign funded enterprises collect less revenue than on average. This could capture an high reliance on domestic firms (and specially SOE) as taxpayers, besides some kind of fiscal incentive in order to attract foreign investors.

Illiteracy rate regressor exhibits a negative, but not always significant, sign since in regions with an high illiteracy rate tax collection is harder. Moreover, regions with an high illiteracy rate are also the less developed and the most devoted to agriculture, so that corporate taxation does not generate relevant amount of revenues ${ }^{16}$.

A slight, but not always significant, pool effect is detected while we observe generally positive, but not significant, coefficients on the dummies capturing congressional cycle and Asian crisis. The coefficients concerning urban-rural consumption ratio are ambiguous and generally not significant. Puzzling the result on dependency ratio, since the coefficients are positive and generally significant: holding constant other variables, regions with an higher dependency rates generate higher fiscal revenues.

\subsection{Some considerations on expenditure and revenue de- terminants}

Let us briefly discuss the results of these first estimations on regional public expenditure and revenues. There are three questions we would like to answer: is there evidence of some redistribution purpose in the allocation policies of Chinese government? Is there evidence of some kind of political cycle? Finally, is this behavior consistent with the prediction (adapted to an autocratic regime) of the main political economy theory tenets?

The answer to the first two questions, at this point of the analysis, is basically no. Considering the relevant and growing intra-regional and inter-regional disparities, there is no clear evidence that the Chinese government is pursuing some kind of serious redistribution policy. Government expenditure is higher, in per capita term, in richer regions, in more internationally open regions and in regions with a more developed industrial and service sector. Some kind of redistribution intention is detectable from the positive coefficient associated with urban-rural consumption ratio for what concerns the expenditure function, and this is sensible since urban-rural disparities are among the main sources of growing inequality (Chang, 2002; Lee, 2000; Lu, 2002) and since almost all the post-Tienanmen political disorders have had, as an origin, the rural areas of the interior regions. Revenues, as well, are higher in richer and more internationally open regions, so an objection could be that it is not clear whether net transfers are, in fact, favoring these regions. Nevertheless, two facts should be considered. First, the analysis was aimed at intercepting possible tactical behavior of the Chinese government. In totalitarian regimes the fiscal structure is peculiar, being revenues prevailingly based on corporate taxes and with a lower relevance

\footnotetext{
${ }^{16}$ Notice that also the share of primary industry over GRP has a negative effect on local revenues.
} 
of personal income tax (Kenny and Winer, 2006). Tactical expenditure, on the other side, is targeted towards well identified social groups or geographical regions, transfers being aimed at gaining political loyalty of citizens. Therefore, tough it is important to map the source of public revenues, the expenditure side is more directly significant for the analysis of tactical behaviors ${ }^{17}$. Second, I have run a regression ${ }^{18}$ on the global amount of resources assigned to each region (per capita local revenues minus per capita local expenditure) and the results confirm only ambiguous results about possible redistribution policies, excluding a clear government will in this sense.

Evidence of the existence of a "political" or "congressional" cycle influencing local fiscal policy is, at this stage of the analysis, not confirmed. The variables pre-congress and post-congress, though with the expected sign, are not significant under almost all of the considered econometric specifications. I will, in any case, come back on this issue in the next section.

Are the facts up to now observed consistent with political economy tenets holding in a democratic context? At this point of the analysis I would say partially consistent. Redistribution is not the main concern of the government, which seems more oriented towards the support of richer and fast growing regions. This is not consistent with the rule that foresee a better treatment for the more politically reactive poor social groups. Anyway, we should consider that effective redistribution among rich, fast developing area, and poor interior regions would be an almost impossible goal for the Chinese government. Hence, pushing for the achievement of high growth rates together with a relaxation of the constraints to labour mobility can be considered an effective strategy for obtaining, ultimately, a redistributive effect (Chang, 2002).

Notice, finally, how Asian crisis dummy is not significant. As previously stated, Chinese public debt and foreign outstanding debt have always been quite limited, so to allow Chinese government not to pay the shock of external crisis as the far-east crisis of $1997^{19}$.

In order to get some more in-depth insights on the determinants of local expenditure policies I will analyze, in the following section, some specific items of local government expenditure: social and structural expenditure.

\footnotetext{
${ }^{17}$ Notice that revenues are less pliable to the willing of politicians and they are more stable against factors that usually tend to influence the expenditure function since revenues depend on a more remarkable set of rules than expenditure. Vice versa, local or national governments may easily increase expenditure (through pork barrel projects or through welfare programs) if they feel this can be useful to increase the support and loyalty of the citizenship. This is particularly evident in democratic settings, where spending policies are often preferred to tax cuts policies in order to increase political support, because they can be more easily targeted.

${ }^{18}$ The results of the regression on net transfers are available upon request.

${ }^{19}$ Anyway, by regressing per capita local expenditure minus per capita local revenue a negative significant sign (but with a low absolute value) is associated with Asian Crisis dummy, highlighting, if any, a small negative effect on net expenditure.
} 


\section{Social and structural expenditure}

Some kinds of expenditure may be more suited to obtain a more immediate political return; I will call these kind of expenditure "social" expenditure. I will analyze, as a representative sample of social expenditure, spending on education, public health, welfare and social security. These kind of expenditure is more directly observable by citizens and acquires a special importance in a country like China, where great part of the population has still a low level of income and the demand for these basic services is high.

Interventions aiming at obtaining higher growth rates, which we will refer to as "structural", can benefit, in the long run, the whole citizenship. We will analyze, as representative sample of structural expenditure, spending on capital constructions, innovation of enterprises and legal system. In the short run, nevertheless, structural interventions are less attractive from a political point of view. ${ }^{20}$

In a democratic context politicians face frequent electoral races and political economic mechanisms often lead to an excess of social over structural expenditure. Nonetheless, Chinese government is not subject to the electoral control of the citizens and can enhance structural policies leading to higher growth rates and lessen the importance of redistribution and social policies. Nevertheless social policies, in a non democratic context, might be relevant in order to reduce the risk of social unrest.

The following section analyzes the selected social and structural expenditure on the same sector of independent variables used in the previous sections.

\subsection{Analysis of social expenditure}

I have chosen, as examples of "social" expenditure, spending on education, public health, welfare and social security ${ }^{21}$.

The reason of studying them separately is twofold. On one side, these categories of expenditure more directly contribute to reducing social inequalities and it is therefore useful to understand how the government has managed them, so to verify if there has been a scope for redistribution in the government behavior. Second, they are more targetable and low income classes are quite sensitive to their changes. Hence, if the government wants to pursue some kind of tactical behavior, it will likely act on these kinds of items within its budget.

The econometric analysis provides with some useful insight on the behavior of the Chinese government.

First, expenditure on education and public health is positively related to income per capita, while welfare and social expenditure is negatively related to GRP. For the first ones, the demand effect prevails and poor citizens, also

\footnotetext{
${ }^{20}$ Though part of the expenditure in items such as infrastructure might be represented by "pork-barrel" projects that are highly targeted and with an high political remuneration.

${ }^{21}$ According to $\mathrm{Xu}$ and Zou (2000) public expenditure may enhance disparities if it's tilted towards middle or high income class instead of towards the poor through the provision of education and health services and social welfare.
} 


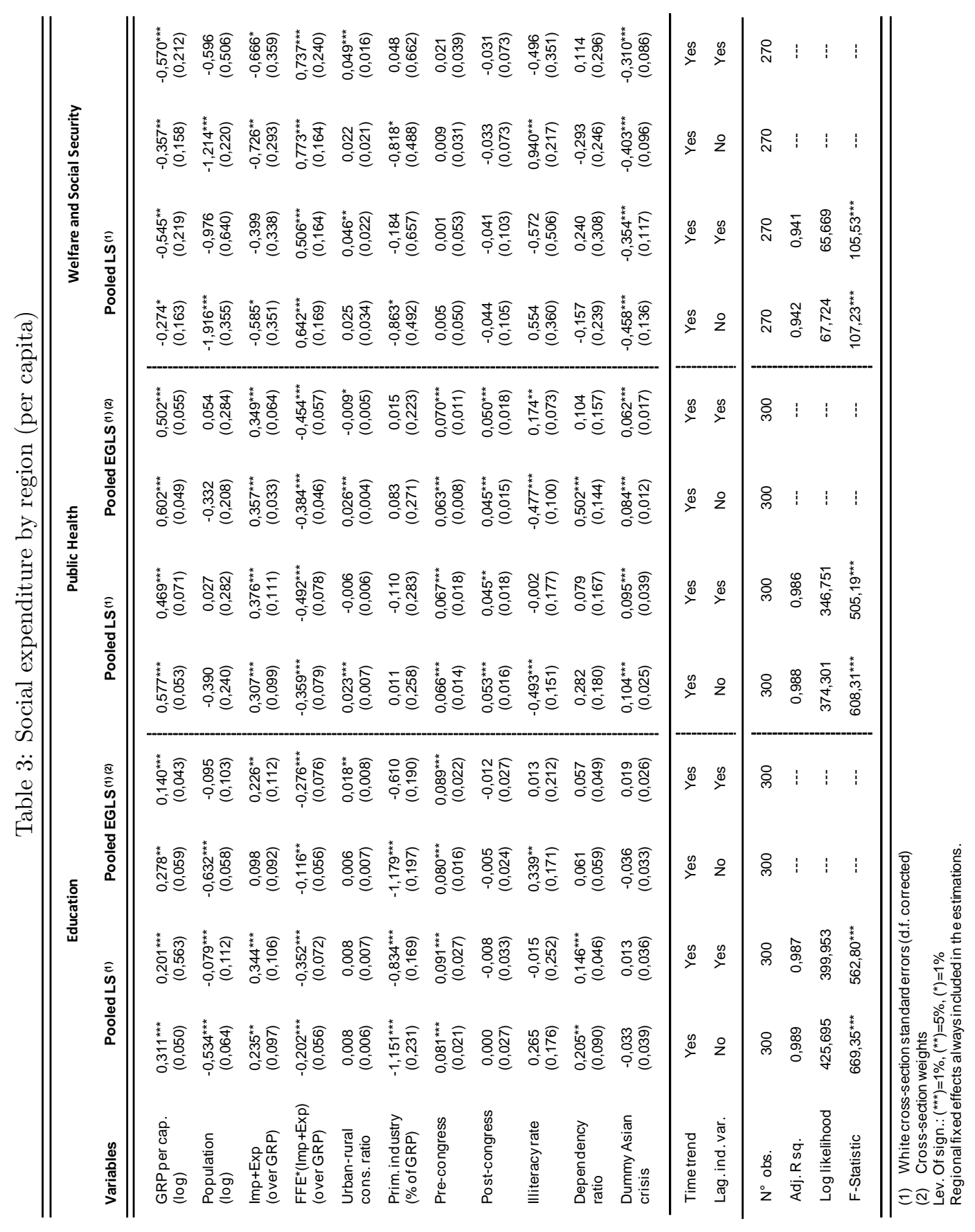


if politically more sensitive, receive less than high demanding middle and high income classes.

If we consider education and public health, further, coefficients associated with international opening have the same sign as in the regression on total expenditure: positive with respect to import-export variables and negative with respect to the presence of foreign funded enterprises. The relationship, curiously, is inverted with respect to expenditure on welfare and social security. A sketched explanation could be that the most open regions are more economically dynamic and need less welfare and social security expenditure. Nevertheless, if trade is lead by foreign funded enterprises, that provide less welfare benefits to their employees, the government directly compensates with a positive spending on these kind of expenditure.

The coefficient related to urban-rural consumption ratio does not exhibit a significant positive relation in most of the regression specifications considered. This fact looks counter intuitive, since reducing inequality should be one of the main goals of these kind of expenditure. It could just mean that the government is more interested in providing public services in growing urban conglomerate than in providing decorous health and education systems in the countryside. This intuition is confirmed by the fact that expenditure on "pure" welfare and social security exhibit a positive, though not always significant, sign. Education is clearly unevenly distributed between urban and rural zones since the sign on the primary industry regressor is always negative and significant.

Asian crisis dummy is significant and negatively correlated with welfare and social security expenditure. While democracies usually expand welfare expenditure when economic growth slows, the Chinese government, that does not respond to a continuous political process control, can vice versa increase productive expenditure instead of redistribution items.

An important result of the section is, finally, the positive, and significant sign (except for what concerns welfare and social security expenditure) associated with the pre-congress variable, pointing out some sort of political cycle in this context.

\subsection{Analysis of structural expenditure}

We will consider, as "structural" expenditure, three examples of spending items that may enhance productivity: capital expenditure, expenditure for enterprises innovation and technical updating and expenditure for rule of law issues ${ }^{22}$.

First, notice that most of the independent variables considered in the model are far less significant in explaining these spending items. The econometric model, realized with the aim of capturing tactical behavior, does not fit as well when trying to explain structural expenditure.

The effects of congress cycles are ambiguous and not generally significant: electoral cyclical spending, also in democracies, is often oriented towards more

${ }^{22}$ Public security agency, procuratorial agency, court and judicial agency. 


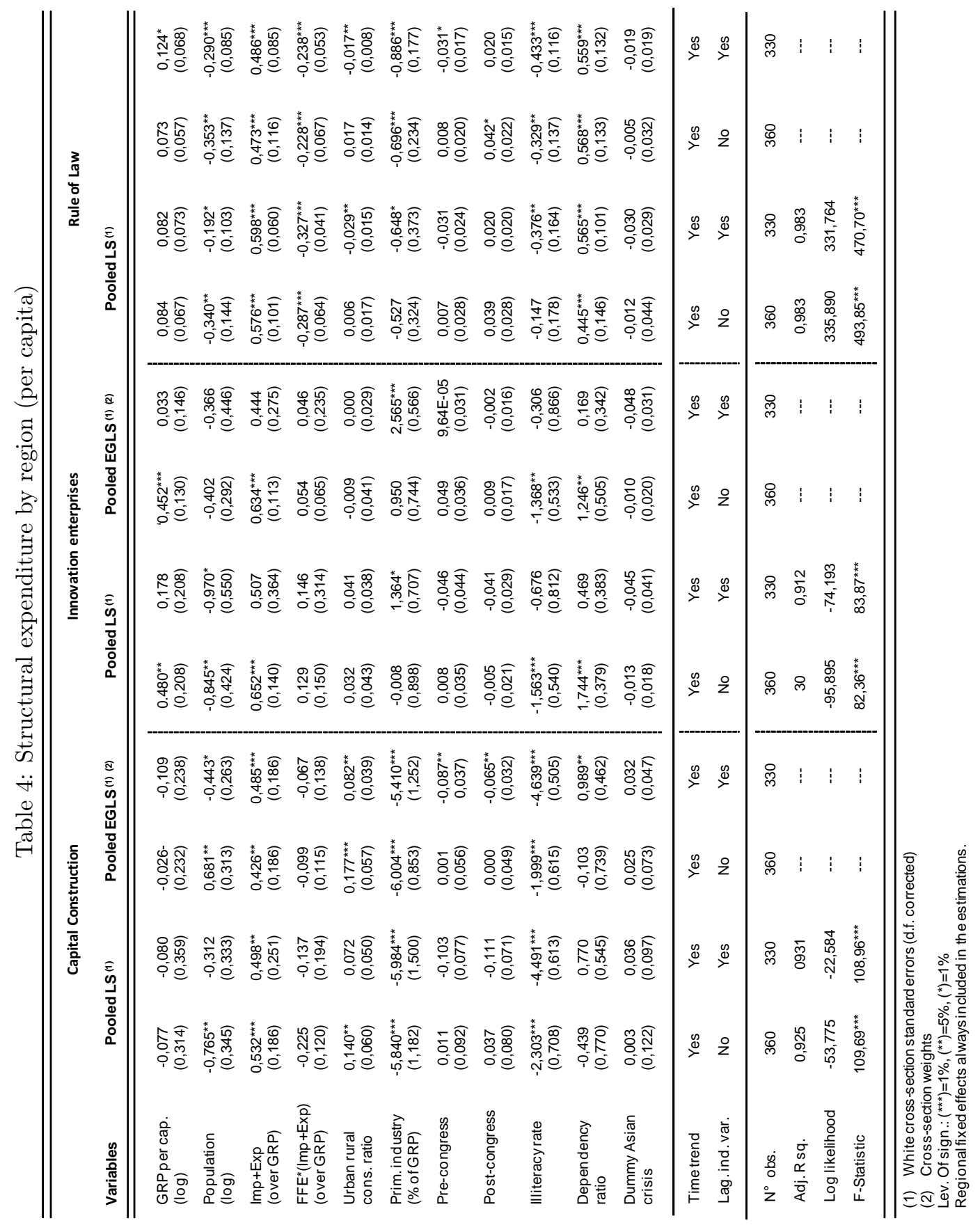


directly redistributive, and targetable, categories of expenditure (instead of towards structural ones).

The coefficients related to dependency ratio, illiteracy rate and, surprisingly, GRP per capita are generally non significant. As noticed in the analysis on the general expenditure function, more internationally open regions attract more public spending: another confirmation that the government is aiming at investing in the creation of highly competitive zones. The fact that the second order decrease in spending in regions where foreign trade is linked to foreign funded firms does not hold for capital construction and enterprise innovation spending further supports this view.

Expenditure on capital constructions is amazingly lower in rural regions (negative coefficient associated with primary industry variables) again confirming the aim of the government of investing in infrastructures in the urbanized coastal regions.

\section{Concluding remarks}

The paper has been exploratory in nature, with the aim of adapting political economy tenets, developed for the analysis of democratic context, to a complex political reality such as modern China. The subject was worthy of analysis: despite a sustained growth that is transforming China in a modern and open economy, no political reform has been pursued by Chinese government. How are the leaders of Chinese communist party managing to maintain the political control over such a wide territory as China, populated by over a billion citizens of different ethnic groups and belonging to differentiated social classes?

I analyzed the determinants of government regional expenditure and revenues, and the determinants of some specific items of the expenditure function: social and structural spending.

The paper sheds some light on the behaviour of the Chinese government.

Redistribution, first of all, seems not to be a priority for Chinese leaders, either because direct redistribution among regions and citizens with such high income differentials would be to a costly, if not impossible, policy or because the priority is to favor the fast economic growth of selected areas postponing nationwide development to a successive phase. Government expenditure is greater in higher income and more internationally open regions. This contrasts with the political economy tenet according to which lower income classes are favored in the redistribution game. Nevertheless, this behavior can be easily interpreted: in fast growing urban cities the demand for public services is higher. Moreover, the provision of public services in developing cities is a priority in order to avoid possible social unrest. The only redistribution evidence that emerges is related to the urban-rural consumption ratio variable. This is not surprising, since urban-rural disparities are increasing and are one of the main cause of the rising inequality in modern China.

There is little evidence of some kind of political cycle influencing public expenditure. Only some kind of social expenditure (education and public health) 
were significantly higher in the years preceding Chinese Communist Party congresses.

Issues such as the development of a pension system and of a more articulated welfare state are gaining positions in the Chinese political agenda. Increasing disparities could be hardly sustainable, and economic growth could disarticulate Chinese traditional three-generation family structure, calling for the need of modern pension and welfare systems. The analysis of the evolution of Chinese government transfers will therefore represent a fundamental issue for future research.

\section{References}

Acemoglu, D. and Robinson, J. (2000). Why Did the West Extend the Franchise? Democracy, Inequality, and Growth in Historical Perspective. Quarterly Journal of Economics, 11:1167-1199.

Acemoglu, D. and Robinson, J. (2001). A Theory of Political Transition. American Economic Review, 91(4):938-963.

Acemoglu, D. and Robinson, J. (2006). Economic Origins of Dictatorship and Democracy. Cambridge University Press, New York.

Alesina, A. and Rodrik, D. (1994). Distributive Politics and Economic Growth. Quarterly Journal of Economics, 2:465-490.

Allen, F., Qian, J., and Qian, M. (2005). Law, finance, and economic growth in China. Journal of Financial Economics, 77:57-116.

Chang, G. (2002). The cause and cure of China's widening income disparity. China Economic Review, 13:335-340.

Conley, J. and Temimi, A. (2001). Endogenous Enfranchisement When Groups' Preferences Conflict. Journal of Political Economy, 109(1):79-102.

Cox, G. and McCubbins, M. (1986). Electoral Politics as a Redistributive Game. Journal of Politics, 48:370-389.

Dickson, B. and Rost Rublee, M. (2000). Membership Has Its Privileges: the Socioeconomics Characteristics of Communist Party Members in Urban China. Comparative Political Studies, 33:87-112.

Dixit, A. and Londregan, J. (1996). The Determinants of Success of Special Interests in Redistributive Politics. Journal of Politics, 58:1132-1155.

Fan, S., Fang, C., and Zhang, X. (2002). Emergence of Urban Poverty and Inequality in China: Evidence from Household Survey. China Economic Review, 13:430-443. 
Giavazzi, F. and Tabellini, G. (2005). Economic and political liberalizations. Journal of Monetary Economics, 52:1297-1330.

Kenny, L. and Winer, S. (2006). Tax Systems in the World: An Empirical Investigation into the Importance of Tax Bases, Administration Costs, Scale and Political Regime. International Tax and Public Finance, 13:181-215.

Krussel, P. and Rios-Rull, J. (2002). Politico-Economic Transition. Review of Economic Design, 7:309-329.

Lee, J. (2000). Changes in the source of China's regional inequality. China Economic Review, 11:232-245.

Li, H., Liu, P., Zhang, J., and Ma, N. (2007). Economic Returns to Communist Party Membership: Evidence from Urban Chinese Twins. Economic Journal, 117:1504-1520.

Lizzeri, A. and Persico, N. (2004). Why Did the Elites Extend the Suffrage? Democracy and the Scope of Government, With an Application to Britain's "Age of Reform". Quarterly Journal of Economics, 119(2):705-763.

$\mathrm{Lu}$, D. (2002). Rural-urban income disparity: impact of growth, allocative efficiency, and local growth welfare. China Economic Review, 13:419-429.

Mulligan, C., Gil, R., and i Martin X., S. (2004). Do Democracies Have Different Public Policies than Nondemocracies. Journal of Economic Perspectives, 18(1):51-74.

Wintrobe, R. (1990). The Tinpot and the Totalitarian: An Economic Theory of Dictatorship. American Political Science Review, 84(3):849-872.

$\mathrm{Xu}$, L. and Zou, H.-f. (2000). Explaining the changes of income distribution in China. China Economic Review, 11:149-170.

Yang, D. (1999). Urban-Biased Policies and Rising Income Inequality in China. American Economic Review, 2(2):306-310.

Yang, D. and Zhou, H. (1999). Rural-urban disparity and sectoral labour allocation in china. Journal of Development Studies, 35(3):105-133. 


\section{Appendix I - Variables definition}

Figure 1: Database structure

\begin{tabular}{|c|c|}
\hline Variable & Description \\
\hline \multicolumn{2}{|c|}{ Dependent variables (general model) } \\
\hline GTEPC & Government total expenditures (percapita) ${ }^{1}$ \\
\hline GTRPC & Government total revenues (per capita) ${ }^{1}$ \\
\hline \multicolumn{2}{|c|}{ Dependent variables (social expenditure) } \\
\hline EDUC & Expenditures in education (per capita) ${ }^{1}$ \\
\hline PUBHEALTH & Expenditures in public health (per capita) ${ }^{1}$ \\
\hline WELSOC & Social welfare \& social security programs (per capita) ${ }^{1}$ \\
\hline \multicolumn{2}{|c|}{ Dependent variables (structural expenditure) } \\
\hline CAP & Expenditures for capital construction (per capita) ${ }^{1}$ \\
\hline INN & Expenditures for innovation enterprises (per capita) ${ }^{1}$ \\
\hline JUST & $\begin{array}{l}\text { Expenditure for public security agency, procuratorial agency and court } \\
\text { of justice (per capita) }{ }^{1}\end{array}$ \\
\hline \multicolumn{2}{|l|}{ Independent variables } \\
\hline GRP per capita & Gross regional product (per capita) ${ }^{1}$ \\
\hline Population & Total regional population \\
\hline $\operatorname{Imp}+\operatorname{Exp}$ & $\begin{array}{l}\text { Import value of commodities by place of destination and export value } \\
\text { of commodities by place of origin in China }\end{array}$ \\
\hline FFE & $\begin{array}{l}\text { Value of Imports and exports of foreign-funded enterprises by } \\
\text { region/GRP }\end{array}$ \\
\hline Urban rural consumption ratio & Urban/rural consumption ratio \\
\hline Primary industry & Gross regional product, primary sector (\% of GRP) \\
\hline Pre-congress & $\begin{array}{l}\text { Dummy equal to } 1 \text { in the year of each congress and in the previous } \\
\text { year }\end{array}$ \\
\hline Post-congress & Dummy equal to 1 in the year following each congress \\
\hline Illiteracy rate & Illiterate population aged 15 and Over \\
\hline Dependency ratio & People aged 0-14 plus population aged 65 and over \\
\hline Dummy Asian crisis & Dummy equal to 1 for the years $1997-1999$ \\
\hline
\end{tabular}

(1) 2000 constant value Yuan 


\section{Appendix II - Analysis for non-autonomous re- gions}

In this appendix the results of the regressions on expenditure and revenue function, limited to non autonomous regions, are considered. In principle, autonomous regions could have local different public tax systems and have an higher degree of independence in setting their public policies. In practice, the major right that Chinese autonomous regions have is the one to appoint the governor chosen from the local minority, but there is not a substantial independency for what concerns the policy decision making process. Nevertheless, it's important to check whether an exclusion of these regions from the general econometric model may have some influence on the results.

By comparing the results in Table 5 with the results obtained in Section 4 , we notice that no major difference emerges by limiting the analysis to non autonomous regions. The policy of Chinese government should not be, therefore, remarkably different towards autonomous versus non autonomous regions. Anyway, we can observe differences in magnitude for what concerns the effect of some of the considered variables.

For what concerns the expenditure function notice that the positive effects of the variables GRP per capita and imports and exports over GRP and the negative effect of the share of primary industry in the economy are remarkably lower, if we consider non autonomous regions alone. Richer and internationally open autonomous regions are therefore better recipients of public expenditure, while the comparative disadvantage of being a prevalently rural region is higher for ordinary regions. The latter variables lose significance if we consider the revenue function, so that tax pressure does not significantly differ between rural and urbanized regions.

In ordinary regions, as in the whole sample, we do not observe a significant cyclicity with respect to the (pre or post) congress variables. 


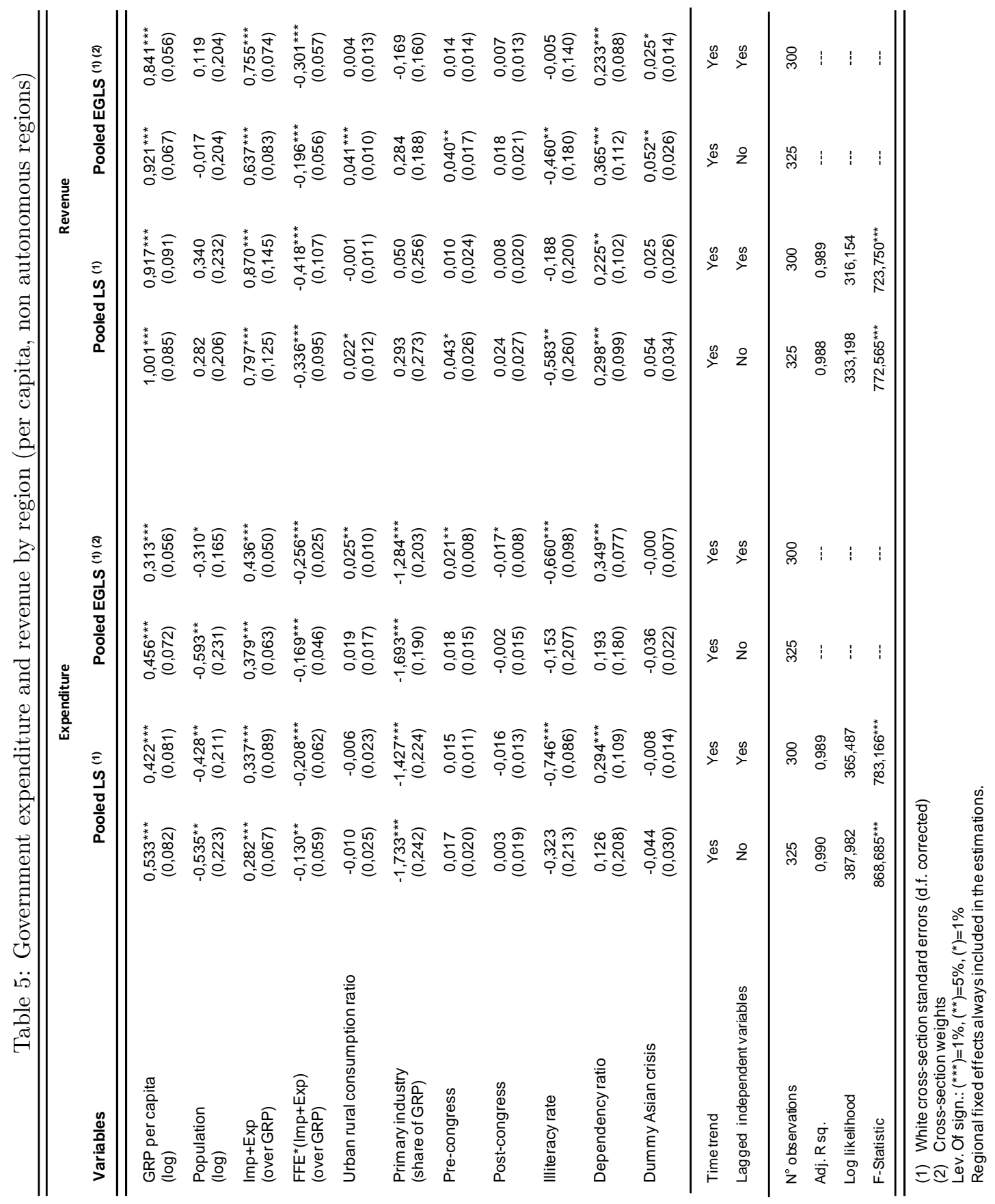

